\title{
PENGARUH CORPORATE GOVERNANCE, UKURAN PERUSAHAAN DAN LAVERAGE TERHADAP MANAJEMEN LABA
}

\author{
Ninik Budianti ${ }^{1}$ \\ Ardiani Ika Sulistyawati ${ }^{2}$ \\ Fakultas Ekonomi Universitas Semarang \\ ardiani@usm.ac.id ${ }^{2}$
}

Diterima: Februari 2019, Disetujui: Maret 2019. Dipublikasikan: April 2019

\begin{abstract}
This study aimed to analyze and test empirically the effect of corporate governance (managerial ownership, institutional ownership, audit committe and independence commissioner), corporate size and Laverage enterprises towards earning management. Discreationary accrual is the proxy of earning management. The data used is secondary data.Population in the research contain 40 banking enterprises,Based on purposive sampling method, data sample set collected 11 banking enterprises listing on the Indonesia Stock Exchange in 2012-2015. To meet the goal of the research hypotheses were tested with multiple regression analysis. Analysis of data to test the structural equation is using SPSS 20. The results showed that managerial ownership, institutional ownership and audit committe have no significant effect on earnings management. independence commissioner, corporate size and laverage have significant effect on earnings management.
\end{abstract}

Keywords : corporate governance, corporate size, laverage, earnings anagement.

\begin{abstract}
ABSTRAK
Penelitian ini bertujuan untuk menganalisis dan menguji secara empiris pengaruh Corporate Governance (Kepemilikan Manajerial, Kepemilikan Institusional, Komite Audit dan Komisaris Independen), Ukuran Perusahaan dan Laverage Terhadap Manajemen Laba . Discreationary accrual digunakan sebagai proksi manajemen laba. Data yang digunakanadalah data sekunder .Populasipadapenelitianiniadalah 40 Perusahaan Perbankan, berdasarkan metode purposive sampling sampel yang diperoleh sebanyak 11 perusahaan perbankan yang terdaftar di Bursa Efek Indonesia pada tahun 2012-2015. Untuk memenuhi sasaran penelitian hipotesis diuji dengan analisis regresi berganda. Analisis data untuk menguji persamaan struktural yaitu menggunakan program SPSS 20. Hasil penelitian menunjukkan bahwa kepemilikan manajerial, kepemilikan institusional dan komite audit tidak berpengaruh terhadap manajemen laba. Dewan komisaris independen, ukuran perusahaan dan laverage berpengaruh terhadap manajemen laba.
\end{abstract}

Kata kunci: Corporate Governance Ukuran Perusahaan, Laverage, Manajemen Laba.

\section{PENDAHULUAN}

Laporan keuangan merupakan salah satu sumber informasi mengenai kondisi dan kinerja suatu perusahaan bagi pihak eksternal. Informasi tersebut menyangkut posisi keuangan, kinerja serta perubahan posisi keuangan suatu perusahaan dan bermanfaat bagi sejumlah besar pemakai dalam pengambilan keputusan ekonomi. Salah satu elemen penting dalam laporan keuangan yang digunakan untuk mengukur kinerja manajemen adalah laba. Informasi laba merupakan perhatian utama untuk menaksir kinerja atau 
prestasi manajemen. Selain itu informasi laba juga digunakan oleh investor atau pihak lain yang berkepentingan sebagai indikator efisiensi penggunaan dana yang tertanam dalam perusahaan yang diwujudkan dalam tingkat pengembalian dan indikator untuk kenaikan kemakmuran (Ghozali dan Chariri, 2007:350) dalam Dian Agustia, 2013.

\section{Gambar 1 \\ Fenomena GAP}

Pada Perusahaan Perbankan di BEI Tahun 2012-2015

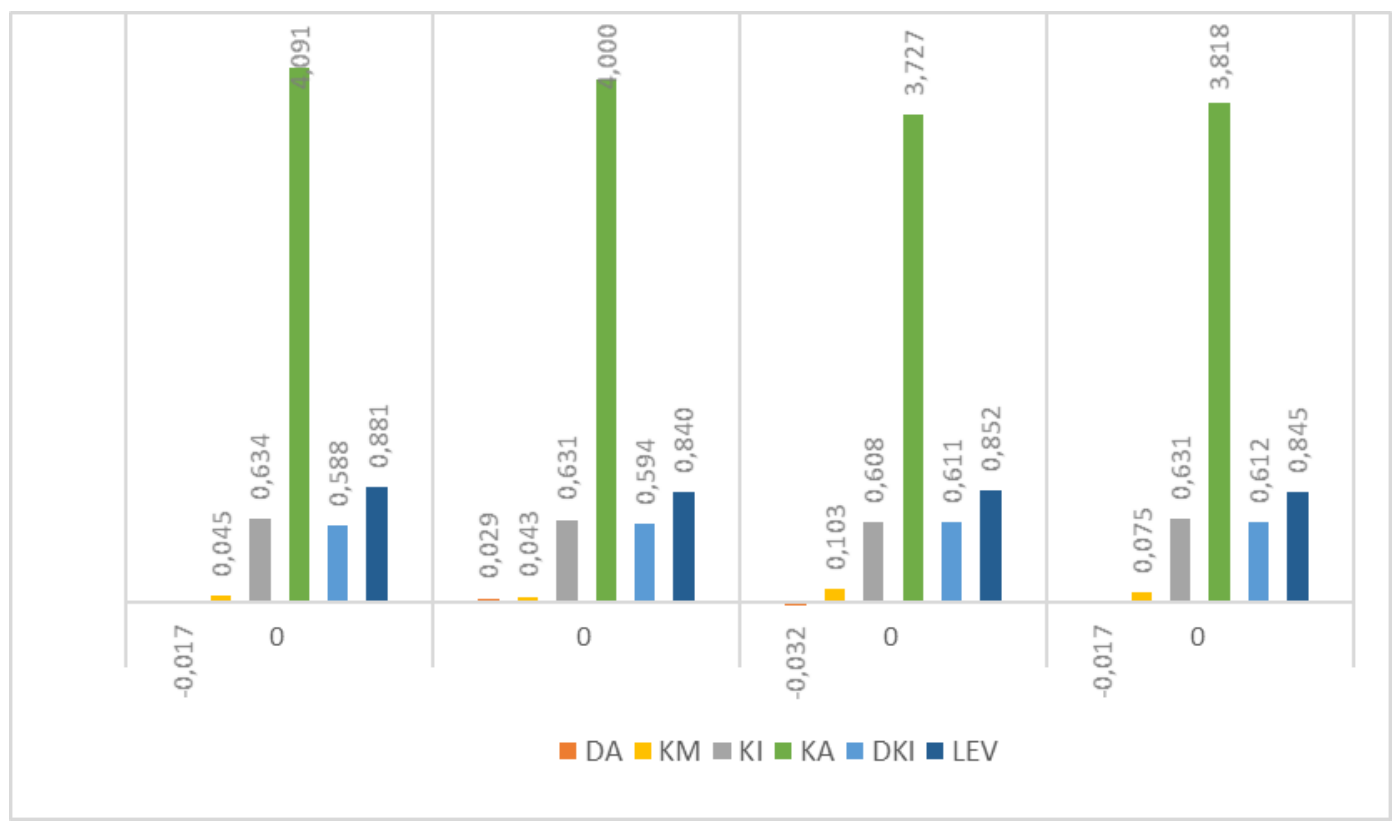

Sumber : BEI, data diolah 2016

Berdasarkan Gambar 1 diatas dapat disimpulkan research problem dalam penelitian ini bahwa manajemen laba yang diukur dengan DA dan Size saat mengalami peningkatan pada tahun 2013, yang berlawanan dengan kepemilikan manajerial dan kepemilikan institusional, DKI mengalami kenaikan yang terus menerus. Dari perubahan pergerakan nilai DA, KM, KI, DKI, Size dan Lev maka menarik untuk meneliti sejauh mana GCG, Size dan Lev bisa mempengaruhi manajemen laba (DA).

Berdasarkan uraian diatas terdapat beberapa faktor yang mempengaruhi terjadinya manajemen laba dalam suatu perusahaan, penelitian ini menggunakan variabel GCG , Ukuran Perusahaan dan Laverage. Penelitian ini mengacu pada penelitian Frendy,dkk (2014). Perbedaan penelitian ini dengan penelitian Frendy,dkk (2014) dalam hal penambahan variabel laverage . 
Objek penelitian yang digunakan dalam penelitian ini adalah Perusahaan Perbankan yang terdaftar di Bursa Efek Indonesia (BEI) periode 2012-2015. Perusahaan Perbankan yang menyajikan laporan keuangan secara lengkap selama periode penelitian.

\section{TELAAH PUSTAKA DAN PENGEMBANGAN HIPOTESIS}

\section{Teori Keagenan (Agency Theory)}

Agency theory merupakan dasar yang digunakan untuk memahami corporate governance. Jensen dan Meckling (1976) dalam Frendy, dkk (2014) menyatakan bahwa agency theory adalah sebuah kontrak antara manajer (disebut dengan agent) dengan pemilik (disebut dengan principal). Agar hubungan kontrak dapat berjalan dengan lancar, pemilik akan mendelegasi otoritas pembuatan keputusan kepada manajer. Perencanaan kontrak yang tepat dimaksudkan untuk menyelaraskan kepentingan manajer dan pemilik dalam hal konflik kepentingan ini lah yang merupakan inti dari agency theory.

Eisenhardt (1989) dalam Emerzon (2007) dalam Frendy, dkk (2014) mengemukakan bahwa teori keagenan dilandasi oleh beberapa asumsi. Asumsi - asumsi tersebut dibagi menjadi tiga jenis, yaitu asumsi tentang sifat manusia, asumsi keorganisasian, dan asumsi informasi. Asumsi sifat manusia menekankan bahwa manusia memiliki sifat mementingkan diri sendiri (self interest), manusia memiliki daya pikir terbatas mengenai persepsi masa mendatang (bounded rationality), dan manusia selalu menghindari resiko (risk averse).

Berdasarkan asumsi sifat dasar manusia dijelaskan bahwa masing - masing individu semata- mata termotivasi oleh kepentingan dirinya sendiri sehingga menimbulkan konflik kepentingan antara principal dan agent . Pihak pemilik (principal) termotivasi mengadakan kontrak untuk menyejahterakan dirinya dengan profitabilitas yang selalu meningkat. Sedangkan manajer (agent) termotivasi untuk memaksimalkan pemenuhan ekonomi dan psikologinya antara lain dalam memperoleh investasi, pinjaman , maupun kontrak kompensasi. Dengan demikian terdapat dua kepentingan yang berbeda didalam perusahaan yang masing- masing pihak berusaha untuk mencapai atau mempertahankan tingkat kemakmuran yang dikehendaki, Frendy, dkk (2014). 


\section{Hubungan Logis Antar Variabel dan Perumusan Hipotesis}

\section{Hubungan Kepemilikan manajerial dengan manajemen laba}

Dari sudut pandang teori akuntansi, manajemen laba sangat ditentukan oleh motivasi manajer perusahaan. Motivasi yang berbeda akan menghasilkan besaran manajemen laba yang berbeda, seperti antara manajer yang juga sekaligus sebagai pemegang saham dan manajer yang tidak sebagai pemegang saham. Hal ini sesuai dengan sistem pengelolaan perusahaan dalam dua kriteria : (1) Perusahaan di pimpin oleh manajer dan pemilik (owner-manager) dan (2) perusahaan yang dipimpin oleh manajer dan bukan pemilik (non owner-manager). Dua kriteria ini akan mempengaruhi manajemen laba, sebab kepemilikan manajer akan ikut menentukan kebijakan dan pengambilan keputusan terhadap metode akuntansi yang diterapkan pada perusahaan yang mereka kelola (Boediono, 2005). Berdasarkan uraian singkat di atas, maka dapat ditarik hipotesis :

H1 : Kepemilikan manajerial berpengaruh signifikan terhadap manajemen laba.

\section{Hubungan kepemilikan institusional dengan manajemen laba}

Tarjo (2008) melakukan penelitian pengaruh konsentrasi kepemilikan institusional terhadap manajemen laba, dimana hasil penelitiannya menyatakan bahwa kepemilikan institusional berpengaruh negatif signifikan terhadap manajemen laba. Namun hasil penelitian Guna dan Herawaty (2010) dan Pradipta (2011) berbeda, yaitu kepemilikan manajerial tidak mempunyai pengaruh terhadap manajemen laba, Frendy, dkk (2014).

Kepemilikan institusional mempunyai pengaruh yang negatif terhadap terhadap praktik manajemen laba, semakin kecil persentase kepemilikan institusional maka semakin besar pula kecendurangan pihak manajer dalam mengambil kebijakan akuntansi tertentu untuk memanipulasi pelaporan laba (Widyastuti, 2009). Hasil tersebut berbeda dengan hasil penelitian oleh Guna dan Herawaty (2010) dan Yang.et al (2009), Oktovianti dan Agustina (2012), yang menghasilkan kesimpulan bahwa variabel kepemilikan institusional tidak berpengaruh terhadap manajemen laba karena investor institusional sebagai pemilik sementara perusahaan lebih terfokus pada current earnings, Dian Agustia (2013). Berdasarkan uraian singkat diatas maka dapat ditarik hipotesis :

H2 : Kepemilikan Institusional berpengaruh signifikan terhadap manajemen laba

\section{Hubungan komite audit dengan manajemen laba}


Komite audit terbentuk mempunyai tanggung jawab sebagai pengawas laporan keuangan hasil audit eksternal dan memonitoring SPI yamg diharapkan dapat mencegah atau meminimalkan sifat opportunistic pihak manajemen yang melakukan praktik manajemen laba (Budi.S, 2009). Hal ini didukung oleh Guna dan Herawaty (2010) yang menyatakan dengan adanya komite audit efektif mencegah atau meminimalkan praktik manajemen laba karena dalam hal ini keberadaan komite audit mengawasi jalannya kegiatan perusahaan dalam mencapai tujuan perusahaan, Prabaningrat dan Widanaputra, (2015). Berdasarkan uraian singkat diatas maka dapat ditarik hipotesis :

H3 : Keberadaan komite audit berpengaruh signifikan terhadap manajemen laba.

\section{Hubungan komisaris independen dengan manajemen laba}

Pengaruh proporsi dewan komisaris independen terhadap manajemen laba pernah diteliti oleh Murhadi (2009), serta Oktovianti dan Agustia (2012). Hasil penelitian ketiga peneliti tersebut menunjukkan bahwa proporsi atau ukuran dewan komisaris independen tidak berpengaruh terhadap manajemen laba. Akan tetapi, hasil penelitian yang dilakukan oleh Kouki, et al. (2011) yang menggunakan sample dari setiap sektor industri menghasilkan simpulan bahwa keberadaan komisaris independen berpengaruh negatif terhadap praktik manajemen laba, Frendy, dkk (2014).Berdasarkan uraian singkat diatas, maka dapat ditarik hipotesis:

H4 :Keberadaan Komisaris Independen berpengaruh signifikan terhadap manajemen laba.

\section{Hubungan Ukuran Perusahaan dengan Manajemen Laba}

Chotrou, dkk (2001) dalam purwanti (2012) menemukan bahwa ukuran perusahaan di Amerika Serikat berpengaruh negatif terhadap manajemen laba. Perusahaan yang lebih besar kurang memiliki dorongan untuk melakukan manajemen laba dibandingkan perusahaan kecil. Sedangkan penelitian di Indonesia oleh Siregar dan Utama (2005) menemukan bahwa ukuran perusahaan yang diukur dengan menggunakan logaritma natural nilai pasar ekuitas perusahaan pada akhir tahun berpengaruh signifikan negatif terhadap besaran pengelolaan laba, artinya semakin besar ukuran perusahaan semakin kecil besaran pengelolaan labanya, dalam Januar dan Farid, (2014). Dari uraian singkat diatas, dapat ditarik hipotesis :

H5 :Ukuran Perusahaan memiliki pengaruh signifikan terhadap manajemen laba. 


\section{Hubungan Rasio Laverage dengan manajemen laba}

Laverage dapat menjadi tolak ukur mengenai manajemen laba yang dilakukan perusahaan. Perusahaan dengan tingkat laverage yang tinggi berarti memiliki liabilitas yang lebih besar jika dibandingkan dengan aset yang dimiliki, hal ini mengakibatkan resiko dan tekanan yang besar pada perusahaan. Shanti dan Yudhanti (2007) dalam Purwanti (2012) menemukan bahwa perusahaan yang memiliki financial laverage tinggi akibat besarnya liabilitas dibandingkan aktiva yang dimiliki perusahaan, diduga melakukan manajemen laba karena perusahaan terancam default, yaitu tidak dapat memenuhi kewajiban membayar liabilitas pada waktunya. Penelitian Chin et al. (2009) juga menemukan bahwa terdapat pengaruh positif laverage terhadap manajemen laba. Penelitian lain yang dilakukan Dichev dan Skinner (2002), Jaggi dan Lee (2002) dan Othman dan Zhegal (2006) juga menemukan hubungan positif antara hutang dan manajemen laba. Januar dan Farid, (2014). Dari uraian singkat diatas dapat ditarik hipotesis :

H 6 : Rasio laverage berpengaruh signifikan terhadap manajemen laba.

\section{METODE PENELITIAN}

Populasi penelitian ini adalah perusahaan Perbankan yang terdaftar di BEI periode 2012-2015, teknik pengambilan sampel dengan purposive sampling adalah metode penentuan sampel dengan pertimbangan tertentu dimana anggota sampel akan dipilih sedemikian rupa sehingga sampel yang dibentuk tersebut dapat mewakili sifat-sifat populasi, yaitu sebagai berikut :

1. Perusahaan Perbankan yang terdaftar di Bursa Efek Indonesia Periode 2012-2015.

2. Perusahaan perbankan yang menyajikan laporan keuangan secara berturut turut selama periode penelitian.

3. Perusahaan perbankan yang menyajikan data keuangan secara lengkap.

\section{Metode Analisis Data}

Penelitian ini menggunakan empat tahapan dalam menganalisis data, yaitu : (1) Analisis Kuantitatif, (2) Uji statistik Deskriptif, (3) Uji Asumsi Klasik, (4) Uji Hipotesis. Penelitian ini menggunakan program SPSS 20.00 untuk pengolahan data. Seberapa besar 
variabel independen mempengaruhi variabel dependen dihitung dengan menggunakan persamaan garis analisis regresi linear berganda, sebagai berikut :

$\mathrm{DA}=\alpha+\beta 1 \mathrm{KM}+\beta 2 \mathrm{KI}+\beta 3 \mathrm{KA}+\beta 4 \mathrm{KoI}+\beta 5 \mathrm{U}+\beta 6 \mathrm{LEV}+\varepsilon$

Keterangan :

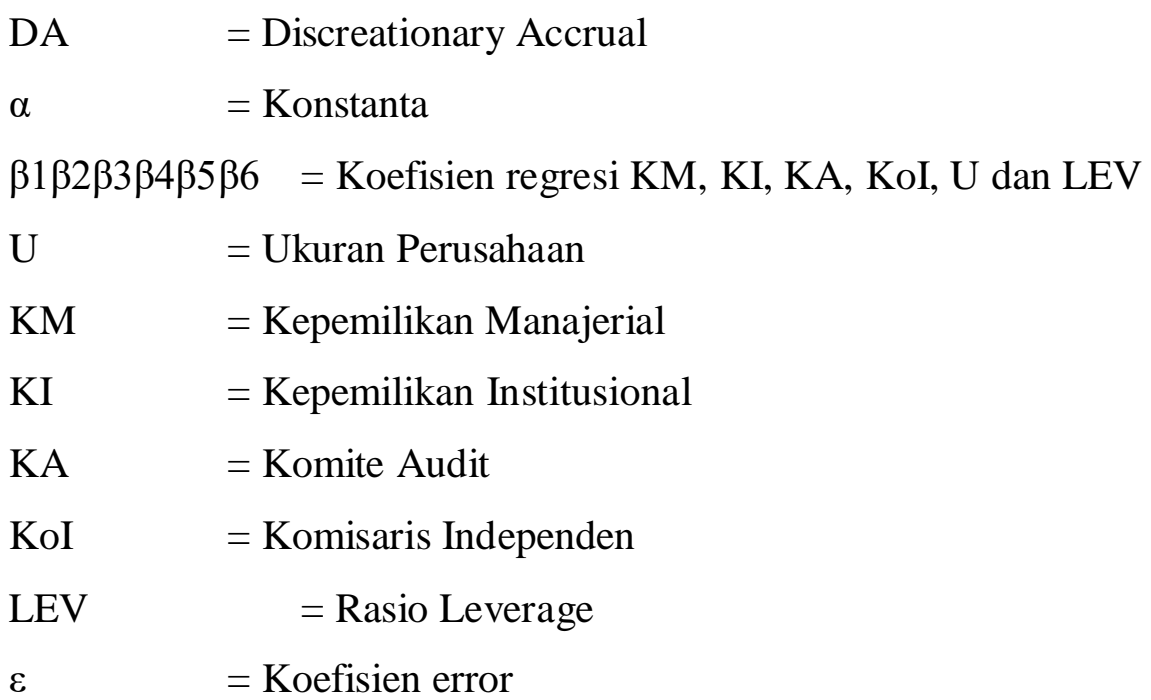

\section{Variabel Penelitian}

a. Variabel Bebas ( Independen Variabel)

Variabel bebas merupakan variabel yang mempengaruhi atau yang menjadi sebab perubahannya atau timbulnya variabel dependen (terikat), dalam penelitian ini variabel independennya adalah : Corporate governance (Kepemilikan manajerial, kepemilikan institusional, komite audit dan komisaris independen), ukuran perusahaan dan leverage.

b. Variabel Terikat ( Dependen Variabel)

Variabel terikat merupakan variabel yang dipengaruhi atau yang menjadi akibat, karena adanya variabel bebas, dalam hal ini variabel dependennya adalah Manajemen Laba.

\section{Definisi Operasional}

\section{Manajemen Laba}

Manajemen laba adalah derajat atau korelasi laba akuntansi suatu perusahaan (entitas) dengan laba ekonominya. Untuk mengukur manajemen laba dilakukan dengan menggunakan proksi discreationary accrual dengan menggunakan Modified Jones Model karena berdasar Dechow et al. (1995). Model ini lebih baik dibanding model Jones 
standar dalam megukur kasus manipulasi pendapatan, Putu Tiya dan I Gusti Ayu, (2016). Model perhitungannya adalah :

$\mathrm{TACit}=\mathrm{NI}$ it $-\mathrm{CFO}$ it

Kemudian menghitung nilai total accrual (TAC) yang diestimasi dengan persamaan regresi berikut :

$\mathrm{TAC}$ it $/ \mathrm{TA}$ it-1 $=\alpha \mathrm{i}(1 / \mathrm{TA}$ it-1) $+\beta 1 \mathrm{i}($ ("REV it $/ \mathrm{TA}$ it-1) $+\beta 2 \mathrm{i}(\mathrm{PPE}$ it/ TA it -1$)+$ $\varepsilon$

Dengan menggunakan koefisien regresi diatas maka dapat dihitung nilai nondiscreationary accrual (NDTA) dengan rumus :

NDTAC it $=\alpha i(1 /$ TA it -1$)+\beta 1 \mathrm{i}(($ (REV it $-" \mathrm{REC}$ it $) / \mathrm{TA}$ it -1$)+\beta 2 \mathrm{i}(\mathrm{PPE}$ it/ TA it-1) $+\varepsilon$

Discreatinary accrual (DTA) merupakan residual yang diperoleh dari estimasi total accrual yang dihitung sebagai berikut :

DTAC $=($ TAC it/TA it-1 $)-$ NDTAC it

Keterangan :

DTAC it $=$ Discreationary accrual perusahaan i pada periode $\mathrm{t}$

NDTAC it $=$ Non Discreationary accrual perusahaan i pada periode $\mathrm{t}$

NI it= Net Income perusahaan i pada periode $\mathrm{t}$

TAC it $=$ Total accrual perusahaan $\mathrm{i}$ pada periode $\mathrm{t}$

$\mathrm{CFO}$ it $=$ Aliran arus kas operasi perusahaan $\mathrm{i}$ pada periode $\mathrm{t}$

$\mathrm{TA}$ it $=$ Total aktiva perusahaan $\mathrm{i}$ pada periode $\mathrm{t}$

$\triangle \mathrm{REV}$ it $=$ Perubahan penjualan perusahaan i pada periode $\mathrm{t}$

PPE it = Aktiva tetap perusahaan i pada periode $\mathrm{t}$

$\triangle \mathrm{REC}$ it $=$ Perubahan piutang perusahaan $\mathrm{i}$ pada periode $\mathrm{t}$

\section{Komisaris Independen}

Komisaris independen adalah anggota dewan komisaris yang tidak terafiliasi dengan manajemen, anggota dewan komisaris lainnya dan pemegang saham pengendali, serta bebas dari hubungan bisnis atau hubungan lainnya yang dapat mempengaruhi kemampuannya untuk bertindak independen atau bertindak demi kepentingan perusahaan (Komite Nasional Kebijakan Governance (KNKG), 2006). Dewan komisaris adalah 
sebuah dewan yang bertugas untuk melakukan pengawasan dan memberikan nasihat kepada direktur Perseroan Terbatas (PT). Ukuran dewan komisaris merupakan jumlah dewan komisaris yang dimiliki oleh sebuah perusahaan dalam menjalankan fundi monitoring dari implementasi kebijakan direksi, Frendy, dkk (2014). Pengukuran dewan komisaris dengan cara menjumlah semua anggota dewan komisaris independen yang berasal dari luar perusahaan dibagi dengan total dewan komisaris pada perusahaan sampel, yaitu dihitung dengan rumus, Frendy, dkk (2014) :

\section{$\mathrm{KoI}=\underline{\text { Jumlah komisaris Independen X 100\% }}$}

Total Dewan komisaris

\section{Komite Audit}

Keberadaan komite audit sekurang - kurangnya terdiri dari 3 anggota, seorang diantaranya komisaris independen perusahaan tercatat sekaligus menjadi dua komite, sedangkan yang lain adalah pihak ekstern yang independen dan minimal salah seorang memiliki kemampuan di bidang akuntansi dan keuangan.

\section{Kepemilikan manajerial}

Kepemilikan manajerial adalah jumlah kepemilikan saham oleh pihak manajemen yang ada pada sebuah perusahaan yang bertugas untuk menentukan kebijakan yang akan diambil atau strategi perusahaan tersebut dalam jangka pendek maupun dalam jangka panjang. Kepemilikan manajerial dihitung dengan rumus, Frendy, dkk, (2014) :

$\mathrm{KM}=\underline{\text { Jumlah saham yang dimiliki manajemen X 100\% }}$

Jumlah saham yang beredar

\section{Kepemilikan Institusional}

Kepemilikan institusional merupakan proporsi kepemilikan saham oleh instansi atau lembaga (perusahaan asuransi, Bank, Perusahaan Investasi) dalam hal ini institusi pemegang saham publik yang diukur dengan persentase jumlah institusi pemegang saham sebagai investor. Kepemilikan institusional dihitung dengan rumus, Frendy, dkk (2014) :

$$
\mathrm{KI}=\frac{\text { Jumlah saham yang dimiliki institusi X 100\% }}{\text { Jumlah saham yang beredar }}
$$




\section{Ukuran Perusahaan}

Ukuran perusahaan (size) adalah variabel yang diproksikan dengan total aset perusahaan . Total aset dipilih sebagai proksi ukuran perusahaan karena tujuan penelitian mengukur ukuran ekonomi perusahaan, Putu Tiya dan I Gusti Ayu, (2016) dengan rumus

Size $=$ Ln (Asset)

Keterangan :

Size $=$ Ukuran perusahaan

Ln = Logaritma natural

Asset $=$ Total aset perusahaan

\section{Leverage}

Leverage adalah perbandingan antara total kewajiban dengan total aktiva perusahaan. Rasio ini menunjukkan besarnya besar aktiva yang dimiliki perusahaan yang dibiayai dengan hutang. Semakin tinggi nilai leverage maka risiko yang akan dihadapi investor akan meminta keuntungan yang semakin besar. Oleh karena itu, semakin besar leverage maka kemungkinan manajer untuk melakukan manajemen laba akan semakin besar (Ma'ruf, 2006 dalam Welvin, 2010), dalam Januar dan Farid, (2014). Rumus perhitungannya adalah sebagai berikut :

LEV $=\quad$ Total Hutang

Total aset

Keterangan :

Leverage $=$ Rasio utang terhadap aktiva

Utang = Total utang pada tahun $\mathrm{t}$

Aktiva $=$ Total aktiva pada tahun $\mathrm{t}$ 


\section{Hasil Penelitian dan Pembahasan \\ Deskripsi Objek Penelitian}

Tabel 1

Penentuan Jumlah Sampel

\begin{tabular}{|l|c|}
\hline \multicolumn{1}{|c|}{ Kriteria Pemilihan Sampel } & Jumlah Perusahaan \\
\hline $\begin{array}{l}\text { Perusahaan Perbankan yang terdaftar pada Bursa Efek Indonesia pada tahun } \\
2012-2015\end{array}$ & 40 \\
\hline $\begin{array}{l}\text { Perusahaan yang tidak terlisting dari penelitian karena : } \\
\text { 1. Perusahaan tidak berturut-turut melakukan pelaporan keuangan selama } \\
\text { periode penelitian }\end{array}$ & $(14)$ \\
2. Perusahaan yang menyajikan laporan keuangannya secara tidak lengkap \\
\hline Total Sampel Penelitian \\
\hline $\begin{array}{l}\text { Jumlah tahun observasi untuk masing-masing tahun penelitian dari } \\
\text { 2012-2015 }\end{array}$ \\
\hline Total analisis data & 41 \\
\hline
\end{tabular}

Sumber: Data Sekunder, diolah 2016

Tabel 2

Daftar Sampel Penelitian

\begin{tabular}{|c|l|l|}
\hline No & \multicolumn{1}{|c|}{ Kode } & \multicolumn{1}{c|}{ Nama Perusahaan } \\
\hline 1 & BACA & Bank Capital Indonesia Tbk. \\
\hline 2 & BBCA & Bank Central Asia Tbk. \\
\hline 3 & BBKP & Bank Bukopin Tbk. \\
\hline 4 & BBNI & Bank Negara Indonesia (Persero) Tbk. \\
\hline 5 & BDMN & Bank Danamon Indonesia Tbk. \\
\hline 6 & BNGA & Bank CIMB Niaga Tbk. \\
\hline 7 & BSIM & Bank Sinarmas Tbk. \\
\hline 8 & BSWD & Bank of India Indonesia Tbk. \\
\hline 9 & BTPN & Bank Tabungan Pensiunan Nasional Tbk. \\
\hline 10 & BVIC & Bank Victoria International Tbk. \\
\hline 11 & SDRA & Bank Himpunan Saudara 1906 Tbk. \\
\hline
\end{tabular}

Sumber : Data sekunder yang diolah, 2016

\section{Analisis Statistik Deskriptif}

Statistik deskriptif digunakan untuk melihat gambaran data. Dalam penelitian ini data yang akan kita ketahui gambarannya adalah kepemilikan manajerial, kepemilikan institusional, komite audit, dewan komisaris independen, ukuran perusahaan, leverage serta manajemen laba pada perusahaan perbankan yang terdaftar pada Bursa Efek Indonesia pada tahun 2012 hingga 2015. Dari data mentah yang telah diinput dapat dilihat nilai maximum, minimum, mean dan standar deviasi dari masing-masing variabel kepemilikan manajerial, kepemilikan institusional, komite audit, dewan 
komisaris independen, ukuran perusahaan, leverage terhadap manajemen laba. Hasil analisis deskriptif dapat dilihat pada tabel 3.

Tabel 3

Analisis Deskriptif

Descriptive Statistics

\begin{tabular}{|l|r|r|r|r|r|}
\hline & $\mathrm{N}$ & Minimum & Maximum & Mean & $\begin{array}{c}\text { Std. } \\
\text { Deviation }\end{array}$ \\
\hline $\mathrm{KM}$ & 44 &, 000012 &, 678221 &, 06652239 &, 145674247 \\
$\mathrm{KI}$ & 44 &, 110318 &, 977509 &, 62613277 &, 244561702 \\
$\mathrm{KA}$ & 44 & 3 & 6 & 3,91 & 1,053 \\
$\mathrm{PDKI}$ & 44 &, 333333 &, 750000 &, 60132589 &, 096071083 \\
SIZE & 44 & 28,563477 & 34,018528 & 31,4325512 & 1,608664180 \\
LEV & 44 &, 555705 &, 929421 &, 85436225 &, 060222219 \\
DA & 44 &,- 229857 &, 134976 &,- 00899905 &, 059868324 \\
Valid N & 44 & & & & \\
(listwise) & & & & \\
\hline
\end{tabular}

Sumber : Data sekunder yang diolah , 2016

\section{Pengujian Uji Asumsi Klasik}

Tabel 4

Hasil Uji Normalitas data

One-Sample Kolmogorov-Smirnov Test

\begin{tabular}{|c|c|c|}
\hline & & $\begin{array}{l}\text { Unstandardized } \\
\text { Residual }\end{array}$ \\
\hline \multicolumn{2}{|l|}{$\mathrm{N}$} & 44 \\
\hline \multirow{3}{*}{ Normal Parameters ${ }^{a, b}$} & Mean & $0 \mathrm{E}-7$ \\
\hline & Std. Deviation & ,05082615 \\
\hline & Absolute & ,092 \\
\hline \multirow[t]{2}{*}{ Most Extreme Differences } & Positive & ,086 \\
\hline & Negative &,- 092 \\
\hline \multicolumn{2}{|l|}{ Kolmogorov-Smirnov Z } & 609 \\
\hline \multicolumn{2}{|l|}{ Asymp. Sig. (2-tailed) } & ,852 \\
\hline
\end{tabular}

a. Test distribution is Normal.

b. Calculated from data.

Sumber : Data sekunder yang diolah 2016

Berdasarkan hasil uji statistik non-parametik Kolmogorov-Smirnov (K-S) pada tabel 4 di atas menunjukkan nilai Kolmogorov-Smirnov residual sebesar 0,609 dan signifikasi 0,852. Jadi dapat disimpulkan bahwa data residual terdistribusi secara 
normal, hal ini dapat dilihat dari nilai signifikansi yang lebih besar dari 0,05. Uji normalitas selanjutnya menggunakan parameter grafik p-p plot. Hasil uji normalitas berdasarkan grafik tersebut seperti pada gambar berikut;

\section{Gambar 2}

\section{Uji Normalitas P-P}

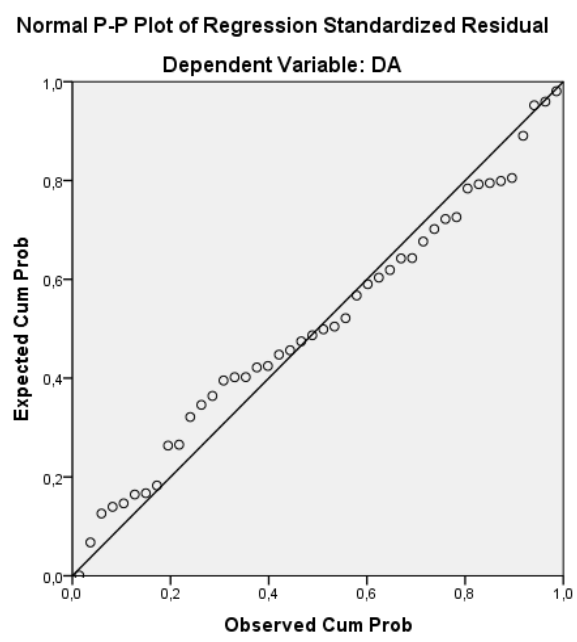

Gambar di atas menjelaskan bahwa data terdistribusi secara normal, karena persebaran data mengikuti atau berhimpit dengan garis diagonal sebagai parameter normalitas. Sehingga baik secara statistik maupun berdasarkan grafik PP Plot data terdistribusi secara normal. Dengan demikian syarat unutk dilakukan uji regresi dapat terpenuhi.

\section{Hasil Uji Multikolinieritas}

Uji multikolinieritas bertujuan untuk mengetahui apakah dalam model regresi berganda ditemukan adanya korelasi antar variabel bebas atau tidak. Gejala multikolonieritas dapat diketahui dengan melihat nilai Variance inflation Faktor (VIF). Hasil Uji Multikolonieritas dapat dilihat pada tabel 5 di bawah ini.

Tabel: 5

Uji Multikolinieritas dengan VIF dan Tolerance

Coefficients $^{a}$

\begin{tabular}{|c|c|c|c|c|c|c|c|}
\hline \multirow[t]{2}{*}{ Model } & \multicolumn{2}{|c|}{$\begin{array}{l}\text { Unstandardized } \\
\text { Coefficients }\end{array}$} & \multirow{2}{*}{$\begin{array}{c}\text { Standardized } \\
\text { Coefficients } \\
\text { Beta }\end{array}$} & \multirow[t]{2}{*}{$\mathrm{t}$} & \multirow[t]{2}{*}{ Sig. } & \multicolumn{2}{|c|}{ Collinearity Statistics } \\
\hline & $\mathrm{B}$ & Std. Error & & & & Tolerance & VIF \\
\hline (Constant) &,- 300 & 255 & & $-1,177$ & 247 & & \\
\hline KM &,- 013 & ,072 &,- 032 &,- 180 & ,858 & ,634 & 1,578 \\
\hline $\mathrm{KI}$ &,- 005 & ,044 &,- 019 &,- 109 & ,914 & ,612 & 1,634 \\
\hline$K A$ & ,006 & ,009 &, 111 & ,716 & ,479 & ,810 & 1,234 \\
\hline
\end{tabular}




\begin{tabular}{l|r|r|r|r|r|r|r|} 
PDKI &, 260 &, 103 &, 417 & 2,534 &, 016 &, 719 & 1,391 \\
SIZE &, 013 &, 006 &, 353 & 2,080 &, 045 &, 676 & 1,480 \\
LEV &,- 350 &, 141 &,- 352 & $-2,478$ &, 018 &, 963 & 1,039 \\
\hline
\end{tabular}

a. Dependent Variable: DA

Sumber : Data sekunder yang diolah 2016

Hasil pengujian pada tabel 5 menunjukkan bahwa variabel independen mempunyai nilai tolerance $>0,10$ dan nilai VIF $<10$. Oleh karena itu dapat diambil kesimpulan bahwa tidak terjadi multikolonieritas diantara variabel independen dan model regresi ini layak dipakai untuk penelitian.

\section{Hasil Uji Autokorelasi}

Tabel: 6

Uji AutoKorelasi dengan Durbin Watson

Model Summary

\begin{tabular}{|r|r|r|r|r|r|}
\hline Model & $R$ & $R$ Square & Adjusted R Square & $\begin{array}{l}\text { Std. Error of the } \\
\text { Estimate }\end{array}$ & Durbin-Watson \\
\hline 1 &, $528^{\mathrm{a}}$ &, 279 &, 162 &, 054792429 & 1,745 \\
\hline
\end{tabular}

a. Predictors: (Constant), LEV, KI, SIZE, KA, PDKI, KM

b. Dependent Variable: DA

Sumber : Data sekunder yang diolah 2016

Pengujian autokorelasi dilakukan dengan menggunakan uji Durbin Watson. Jika nilai DW berada diantara dl dan 4 - dl maka menunjukkan tidak adanya masalah autokotrelasi dalam model regresi. Sedangkan penelitian ini memperoleh nilai DW sebesar 1,745. Nilai DW tersebut berada antara dl dengan du, yang artinya tidak ada hipotesis untuk hasil demikian. Selanjutnya dalam uji autokorelasi ini secara statistik dilakukan uji non-parametriks runs.

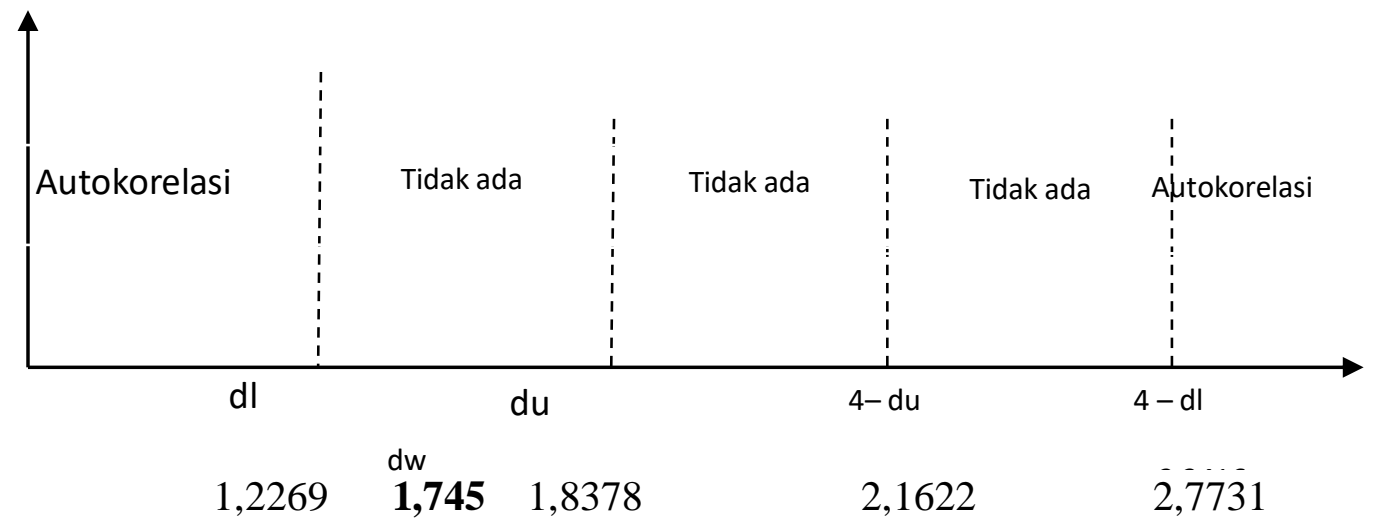


Pada hasil uji non-parametriks runs mendapatkan hasil berikut;

Tabel 7

Uji AutoKorelasi dengan Runs

\begin{tabular}{|l|r|}
\hline \multicolumn{2}{|c|}{ Runs Test } \\
\hline Test Value $^{\mathrm{a}}$ & Unstandardized Residual \\
Cases < Test Value &,- 00099 \\
& 22 \\
Cases >= Test Value & 22 \\
Total Cases & 44 \\
Number of Runs & 24 \\
Z &, 153 \\
Asymp. Sig. (2-tailed) &, 879 \\
\hline
\end{tabular}

a. Median

Hasil uji non-parametrik Runs di atas menunjukkan bahwa nilai signifikansi yang diperoleh sebesar 0,879, lebih besar dari 0,05. Yang artinya model persamaan ini layak digunakan sebagai model uji regresi berganda.

\section{Hasil Uji Heteroskedastisitas}

Hasil pengujian heteroskedastisitas pada penelitian ini dapat dilihat pada tabel 8

Tabel 8 Uji Heteroskedastisitas dengan Uji Spearman

\begin{tabular}{|l|c|}
\hline \multicolumn{1}{|c|}{ Variabel Independen } & Nilai Signifikansi \\
\hline Kep. Manajerial & 0,357 \\
\hline Kep. Institusional & 0,595 \\
\hline Komite Audit & 0,435 \\
\hline Proposi Dewan Komisaris Independen & 0,276 \\
\hline Ukuran Perusahaan & 0,377 \\
\hline Leverage & 0,453 \\
\hline
\end{tabular}

Sumber : Data sekunder yang diolah SPSS

Tabel diatas menunjukkan bahwa semua variabel bebas yang diteliti memiliki nilai signifikansi di atas 0,05 . Yang artinya dalam pengujian heteroskedastisitas ini semua variabel bebas yang diuji layak dalam uji analisis regresi berganda . Dapat dikatakan bahwa variabel-variabel kepemilikan manajerial, kepemilikan institusional, komite audit, dewan komisaris independen, ukuran perusahaan, leverage memenuhi syarat dalam pengujian regresi yang diduga berpengaruh terhadap manajemen laba. 


\section{Analisis Regresi Berganda}

Penelitian ini adalah untuk melihat apakah terdapat pengaruh antara variabel independen terhadap manajemen laba. Dari analisis menggunakan SPSS versi 20.00. Dari hasil olah data didapatkan hasil sebagai berikut :

Tabel 9

Analisis Regresi

Coefficients $^{a}$

\begin{tabular}{|c|c|c|c|c|c|c|c|}
\hline \multirow[t]{2}{*}{ Model } & \multicolumn{2}{|c|}{$\begin{array}{l}\text { Unstandardized } \\
\text { Coefficients }\end{array}$} & \multirow{2}{*}{$\begin{array}{c}\text { Standardized } \\
\text { Coefficients } \\
\text { Beta } \\
\end{array}$} & \multirow[t]{2}{*}{$\mathrm{t}$} & \multirow[t]{2}{*}{ Sig. } & \multicolumn{2}{|c|}{ Collinearity Statistics } \\
\hline & $\mathrm{B}$ & Std. Error & & & & Tolerance & VIF \\
\hline (Constant) &,- 300 & ,255 & & $-1,177$ & ,247 & & \\
\hline KM &,- 013 & ,072 &,- 032 &,- 180 & ,858 & ,634 & 1,578 \\
\hline $\mathrm{KI}$ &,- 005 & ,044 &,- 019 &,- 109 & ,914 & ,612 & 1,634 \\
\hline KA &, 006 & ,009 & ,111 & ,716 & ,479 & ,810 & 1,234 \\
\hline PDKI & ,260 & ,103 & ,417 & 2,534 & ,016 & ,719 & 1,391 \\
\hline SIZE &, 013 & ,006 & ,353 & 2,080 & ,045 & ,676 & 1,480 \\
\hline LEV &,- 350 & ,141 &,- 352 & $-2,478$ & ,018 & ,963 & 1,039 \\
\hline
\end{tabular}

a. Dependent Variable: DA

Sumber : Data sekunder yang diolah 2016

Dari tabel 9 dapat dibuat persamaan matematis sebagai berikut.

$$
\begin{aligned}
\mathrm{D} \alpha= & -0,300-0,013 \beta \mathrm{X} 1-0,005 \beta \mathrm{X} 2+0,006 \beta \mathrm{X} 3+0,260 \beta \mathrm{X} 4+ \\
& 0,013 \beta \mathrm{X} 5-0,350 \beta \mathrm{X} 6+\mathrm{e}
\end{aligned}
$$

\section{Hasil Uji Hipotesis}

\section{Hasil Uji Koefisien Determinasi (R2)}

Koefisiensi determinasi (R2) mengukur seberapa jauh kemampuan model dalam menjelaskan variasi variabel dependen sangat terbatas. Nilai yang mendekati satu berarti variabel-variabel independen memberikan hampir semua informasi yang dibutuhkan untuk memprediksi variabel dependen. Koefisien determinasi dari penelitian ini ditujukkan pada tabel berikut:

Tabel 10

Uji Determinasi $\mathrm{R}^{2}$

Model Summary

\begin{tabular}{|r|r|r|r|r|r|}
\hline Model & $R$ & R Square & Adjusted R Square & $\begin{array}{c}\text { Std. Error of the } \\
\text { Estimate }\end{array}$ & Durbin-Watson \\
\hline 1 &, $528^{\mathrm{a}}$ &, 279 &, 162 &, 054792429 & 1,745 \\
\hline
\end{tabular}

a. Predictors: (Constant), LEV, KI, SIZE, KA, PDKI, KM

b. Dependent Variable: DA 
Tabel diatas memperlihatkan bahwa nilai adjusted R2 yang diperoleh adalah 0,162, atau sama dengan 16,2 persen. Keadaan ini menunjukkan bahwa variabel independen yaitu kepemilikan manajerial, kepemilikan institusional, komite audit, dewan komisaris independen, ukuran perusahaan, leverage memberi kontribusi pengaruh sebesar 16,2 persen terhadap tingkat variabel dependen yaitu manajemenlaba. Sedangkan sisanya 83,8 persen dipengaruhi oleh variabel lain yang tidak disebutkan dalam penelitian ini.

Kecilnya nilai koefisien determinasi karena secara statistik tidak semua variabel berpengaruh terhadap manajemen laba. Bahkan dari ketiga variabel yang berpengaruh terdapat satu variabel yang berpengaruh secara negatif, sehingga secara simultan tidak semua variabel berhubungan searah dengan perubahan manajemen laba.

\section{Hasil Uji Simultan (F)}

Uji statistik F pada dasarnya menunjukkan apakah semua variabel independen atau bebas yang dimasukkan dalam model mempunyai pengaruh secara bersama-sama terhadap variabel dependen/terikat (Ghozali, 2011).

Tabel 11

Uji Simultan (F)

\begin{tabular}{|c|c|c|c|c|c|c|}
\hline \multicolumn{7}{|c|}{ ANOVA $^{a}$} \\
\hline & Model & Sum of Squares & df & Mean Square & $\mathrm{F}$ & Sig. \\
\hline \multirow{3}{*}{1} & Regression & ,043 & 6 & \multirow{3}{*}{$\begin{array}{l}\text {,007 } \\
\text { 0003 }\end{array}$} & \multirow[t]{3}{*}{2,389} & \multirow[t]{3}{*}{, $047^{b}$} \\
\hline & Residual &, 111 & 37 & & & \\
\hline & Total & ,154 & 43 & & & \\
\hline
\end{tabular}

a. Dependent Variable: DA

b. Predictors: (Constant), LEV, KI, SIZE, KA, PDKI, KM

Tabel uji $\mathrm{F}$ di atas menunjukkan hasil uji statistik dengan signifikansi sebesar 0,047. Dengan ketentuan bahwa nilai signifikansi kurangdari 0,05 artinya bahwa ada pengaruh yang signifikan dari variabel bebas secara bersama-sama terhadap variabel dependen. Dengan kata lain kepemilikan manajerial, kepemilikan institusional, komite audit, dewan komisaris independen, ukuran perusahaan, leverage secara bersama-sama mempengaruhi manajemen laba. 


\section{Hasil Uji Hipotesis secara Parsial ( t-Test )}

Uji t digunakan untuk mengetahui ada tidaknya pengaruh secara linier antara variabel bebas dan variabel terikat. Hasil pengujian parsial tersebut dapat dillihat pada tabel 12 berikut:

Tabel 12

Uji Parsial (Uji t)

Coefficients $^{\mathrm{a}}$

\begin{tabular}{|c|c|c|c|c|c|c|c|c|}
\hline \multirow{2}{*}{\multicolumn{2}{|c|}{ Model }} & \multicolumn{2}{|c|}{$\begin{array}{l}\text { Unstandardized } \\
\text { Coefficients }\end{array}$} & \multirow{2}{*}{$\begin{array}{c}\text { Standardized } \\
\text { Coefficients } \\
\text { Beta }\end{array}$} & \multirow[t]{2}{*}{$\mathrm{t}$} & \multirow[t]{2}{*}{ Sig. } & \multicolumn{2}{|c|}{$\begin{array}{l}\text { Collinearity } \\
\text { Statistics }\end{array}$} \\
\hline & & $B$ & Std. Error & & & & Tolerance & VIF \\
\hline \multirow{7}{*}{1} & Constant) &,- 300 & ,255 & & $-1,177$ & ,247 & & \\
\hline & $\mathrm{KM}$ &,- 013 & ,072 &,- 032 &,- 180 & ,858 & ,634 & 1,578 \\
\hline & $\mathrm{KI}$ &,- 005 & ,044 &,- 019 &,- 109 & ,914 & ,612 & 1,634 \\
\hline & $\mathrm{KA}$ & ,006 & ,009 & ,111 & ,716 & ,479 & ,810 & 1,234 \\
\hline & PDKI & ,260 & 103 & ,417 & 2,534 & ,016 & ,719 & 1,391 \\
\hline & SIZE & ,013 & ,006 & ,353 & 2,080 & ,045 & 676 & 1,480 \\
\hline & LEV &,- 350 & ,141 &,- 352 & $-2,478$ & ,018 &, 963 & 1,039 \\
\hline
\end{tabular}

a. Dependent Variable: DA

Sumber : Data sekunder yang diolah 2016

Tabel 12 menunjukkan nilai t hitung untuk masing-masing variabel :

1. Hipotesis pertama menyatakan bahwa kepemilikan manajerial berpengaruh terhadap manajemen laba. Berdasarkan hasil uji statistik thitung menunjukan signifikasi kepemilikan manajerial yaitu sebesar 0,858>0.05 sehingga dapat dibuktikan bahwa $\mathrm{H} 1$ ditolak dan dapat disimpulkan bahwa kepemilikan manajerial tidak berpengaruh terhadap manajemen laba.

2. Hipotesis kedua menyatakan bahwa kepemilikan institusional berpengaruh terhadap manajemen laba. Berdasarkan hasil uji statistik thitung menunjukan signifikasi kepemilikan institusional yaitu sebesar 0,914 > 0.05 sehingga dapat dibuktikan bahwa $\mathrm{H} 2$ ditolak dan dapat disimpulkan bahwa kepemilikan institusional tidak berpengaruh terhadap manajemen laba.

3. Hipotesis ketiga menyatakan bahwa komite audit berpengaruh terhadap manajemen laba. Berdasarkan hasil uji statistik thitung menunjukan signifikasi komite audit yaitu sebesar 0,479>0.05 sehingga dapat dibuktikan bahwa H3 ditolak dan dapat disimpulkan bahwa komite audit tidak berpengaruh terhadap manajemen laba.

4. Hipotesis keempat menyatakan bahwa dewan komisaris independen berpengaruh terhadap manajemen laba. Berdasarkan hasil uji statistik thitung menunjukan 
signifikasi dewan komisaris independen yaitu sebesar $0,016<0.05$ sehingga dapat dibuktikan bahwa $\mathrm{H} 4$ diterima dan dapat disimpulkan bahwa dewan komisaris independen berpengaruh terhadap manajemen laba.

5. Hipotesis kelima menyatakan bahwa ukuran perusahaan berpengaruh terhadap manajemen laba. Berdasarkan hasil uji statistik thitung menunjukan signifikasi ukuran perusahaan yaitu sebesar 0,045 $<0.05$ sehingga dapat dibuktikan bahwa H5 diterima dan dapat disimpulkan bahwa ukuran perusahaaan berpengaruh terhadap manajemen laba.

6. Hipotesis keenam menyatakan bahwa leverage berpengaruh terhadap manajemen laba. Berdasarkan hasil uji statistik thitung menunjukan signifikasi leverage yaitu sebesar $0,018<0.05$ sehingga dapat dibuktikan bahwa H6 diterima dan dapat disimpulkan bahwa leverage berpengaruh terhadap manajemen laba.

\section{Pembahasan}

\section{Pengaruh Kepemilikan Manajerial Terhadap Manajemen Laba}

Hasil analisis menunjukkan bahwa kepemilikan manajerial tidak berpengaruh signifikan terhadap manajemen laba. Dibuktikan dengan nilai signifikansi 0,858 (> 0,05). Dengan hasil tersebut, maka hipotesis pertama dinyatakan ditolak. Hal ini sesuai dengan penelitian yang dilakukan oleh Dian Agustia (2013) yang menyatakan bahwa kepemilikan manajerial tidak berpengaruh terhadap manajemen laba.

Pada perusahaan Bank Capital Indonesia Tbk misalnya, pada tahun 2013 kepemilikan manajerial mengalami nilai peningkatan dari 0,22 menjadi 0,28 , namun

nilai manajemen laba mengalami penurunan dari 0,009 menjadi $-0,015$. Selanjutnya pada tahun 2014 kepemilikan manajerial tidak mengalami perubahan, sedangkan nilai manajemen laba kembali mengalami penurunan dari tahun sebelumnya menjadi $-0,09$. Dan pada tahun 2015 kepemilikan manajerial mengalami penurunan menjadi 0,08 dari tahun sebelumnya, sedangkan manajemen laba mengalami peningkatan dari tahun sebelumnya menjadi -0,08. Data tersebut menunjukkan bahwa perubahan kepemilikan manajerial tidak selalu berhubungan dengan manajemen laba. 


\section{Pengaruh Kepemilikan Institusional Terhadap Manajemen Laba}

Hasil analisis menunjukkan bahwa kepemilikan institusional tidak berpengaruh signifikan terhadap manajemen laba. Dibuktikan dengan nilai signifikansi 0,914 (> 0,05). Dengan hasil tersebut, maka hipotesis kedua dinyatakan ditolak. Hal ini sesuai dengan penelitian yang dilakukan oleh Dian Agustia (2013) yang menyatakan bahwa kepemilikan institusional tidak berpenagruh terhadap manajemen laba.

Pada perusahaan Bank CIMB Niaga Tbk pada tahun 2013 nilai kepemilikan institusional tidak mengalami perubahan dari tahun sebelumnya yakni sebesar 0,97, sedangkan nilai manajemen laba pada tahun 2013 mengalami peningkatan dari tahun sebelumnya menjadi 0,0008. Pada tahun 2014 kepemilikan institusional mengalami penurunan dari tahun sebelumnya menjadi 0,56 , hal ini berlaku sebaliknya pada nilai manajemen laba yang mengalami kenaikan dari tahun sebelumnya menjadi 0,017. Dan pada tahun 2015 kepemilikan institusional tidak mengalami perubahan dari tahun sebelumnya, sedangkan nilai manajemen laba mengalami penuruan dari tahun sebelumnya menajdi $-0,026$. Hal ini menjadi salah satu bukti bahwa perubahan kepemilikan institusional tidak selalu diikuti oleh perubahan manajemen laba.

\section{Pengaruh Komite Audit Terhadap Manajemen Laba}

Hasil analisis menunjukkan bahwa komite audit tidak berpengaruh signifikan terhadap manajemen laba. Dibuktikan dengan nilai signifikansi 0,479 (>0,05). Dengan hasil tersebut, maka hipotesis ketiga dinyatakan ditolak. Hal ini sesuai dengan penelitian yang dilakukan oleh Dian Agustia (2013) yang menyatakan bahwa komite audit tidak berpenagruh terhadap manajemen laba.

Pada perusahaan Bank Victoria International Tbk selama periode penelitian dari tahun 2012 - 2015 tidak mengalami perubahan nilai komite audit, namun hal ini berbeda dengan perubahan pada nilai manajemen laba. Pada tahun 2013 manajemen laba Bank Victoria International Tbk mengalami peningkatan menjadi 0,048, selanjutnya pada tahun 2014 manajemen laba mengalami penurunan menjadi -0,045. Dan pada tahun 2015 manajemen laba mengalami peningkatan dari tahun sebelumnya menjadi -0,02. Dengan demikian hal ini menjadi bukti bahwa perubahan manajemen laba tidak selalu berdasar dari perubahan komite audit sebuah perusahaan. 


\section{Pengaruh Dewan Komisaris Independen Terhadap Manajemen Laba}

Hasil analisis menunjukkan bahwa dewan komisaris independen berpengaruh signifikan terhadap manajemen laba. Dibuktikan dengan nilai signifikansi 0,016 (< 0,05). Dengan hasil tersebut, maka hipotesis keempat dinyatakan diterima. Hal ini sesuai dengan penelitian yang dilakukan oleh Frendy, dkk (2014) yang menyatakan bahwa dewan komisaris independen berpengaruh signifikan terhadap manajemen laba.

Data penelitian menunjukkan bahwa sebagian besar proporsi dewan komisaris independen tidak terlalu menunjukkan perubahan selama periode penelitian. Namun ada perubahan yang menunjukkan adanya hubungan dengan perubahan manajemen laba. Pada tahun 2014 Bank of India Indonesia Tbk mengalami penurunan laba dari tahun sebelumnya hingga $-0,23$, hal ini juga terjadi pada penurunan proporsi dewan komisaris independen pada tahun 2014 dari tahun sebelumnya menjadi 0,33. Pada tahun 2014 Bank CIMB Niaga Tbk mengalami kenaikan laba menjadi 0,0175, perubahan dengan arah kenaikan juga terjadi pada proporis dewan komisaris independen menjadi 0,67 .

Dewan komisaris independen juga mempunyai peranan dalam menerapkan strategi perusahaan guna mendapatkan keuntungan yang meningkat dari periode sebelumnya. Peningkatan proporsi dewan komisaris independen memberikan kesempatan untuk mendapatkan beberapa alternatif pelaksanaan strategi kebijakan perusahaan. Dengan beragamnya alternatif strategi yang disaranakan dewan komisaris independen menjadi mempermudah peningkatan laba perusahaan. Sehingga peran dewan komisaris independen ini akan berfungsi dengan baik jika mampu meningkatkan laba perusahaan.

\section{Pengaruh Ukuran Perusahaan Terhadap Manajemen Laba}

Hasil analisis menunjukkan bahwa ukuran perusahaan berpengaruh signifikan terhadap manajemen laba. Dibuktikan dengan nilai signifikansi 0,045 $(<0,05)$. Dengan hasil tersebut, maka hipotesis kelima dinyatakan diterima. Hal ini sesuai dengan penelitian yang dilakukan oleh Kusumawardhani (2012) yang menyatakan bahwa ukuran perusahaan berpengaruh signifikan terhadap manajemen laba.

Arah perubahan manajemen laba sesuai dengan arah perubahan ukuran perusahaan. Hal in seperti yang dialami oleh Bank Victoria International Tbk, pada tahun 2013 
ukuran perusahaan mengalami peningkatan menjadi 30,58, pada tahun yang sama manajemen laba juga mengalami peningkatan menjadi 0,048. Tahun 2014 ukuran perusahaan mengalami penurunan menjadi 29,91, perubahan ini juga terjadi pada penurunan nilai manajemen laba menjadi -0,45. Dan pada tahun 2015 ukuran perusahaan mengalami kenaikan menjadi 29,94, hal ini juga terjadi pada nilai manajemen laba yang mengalami kenaikan pula menjadi $-0,02$.

\section{Pengaruh Leverage Terhadap Manajemen Laba}

Hasil analisis menunjukkan bahwa leverage berpengaruh signifikan terhadap manajemen laba. Dibuktikan dengan nilai signifikansi 0,018 $(<0,05)$. Dengan hasil tersebut, maka hipotesis keenam dinyatakan diterima. Hal ini sesuai dengan penelitian yang dilakukan oleh Oktavianti dan Agustia (2012) yang menyatakan bahwa leverage perusahaan berpengaruh terhadap praktek manajemen laba.

Pada hasil analisis regresi menunjukkan bahwa leverage berpengaruh secara negatif terhadap manajemen laba. Dengan asumsi bahwa jika perubahan leverage meningkat maka nilai manajemen laba cenderung akan mengalami penurunan dan atau sebaliknya. Hal ini terjadi pada perusahaan Bank CIMB Niaga Tbk. Pada tahun 2013 leverage mengalami penurunan menjadi 0,881, namun nilai manajemen laba mengalami peningkatan menjadi 0,0008. Tahun selanjutnya yakni 2014, leverage masih mengalami penurunan menjadi 0,85 , sedangkan nilai manajemen laba kembali mengalami peningkatan menjadi 0,0175. Sedangkan pada tahun 2015, leverage mengalami peningkatan menjadi 0,86 , hal ini berlaku sebaliknya pada perubahan nilai manajemen laba yang mengalami penurunan menjadi -0,026.

Dalam teori keagenan, semakin dekat perusahaan dengan pelanggaran perjanjian hutang yang berbasis akuntansi, lebih memungkinkan manajer perusahaan untuk memilih prosedur akuntansi yang memindahkan laba yang dilaporkan dari periode masa yang akan datang ke periode masa saat ini (Watts and Zimmerman,1986), dalam Dian Agustia, (2013). Laverage dapat menjadi tolak ukur mengenai manajemen laba yang dilakukan perusahaan. Perusahaan dengan tingkat laverage yang tinggi berarti memiliki liabilitas yang lebih besar jika dibandingkan dengan aset yang dimiliki, hal ini mengakibatkan resiko dan tekanan yang besar pada perusahaan. Shanti dan Yudhanti (2007) dalam Purwanti (2012) menemukan bahwa perusahaan yang memiliki financial 
laverage tinggi akibat besarnya liabilitas dibandingkan aktiva yang dimiliki perusahaan, diduga melakukan manajemen laba karena perusahaan terancam default, yaitu tidak dapat memenuhi kewajiban membayar liabilitas pada waktunya.

\section{Kesimpulan dan Saran}

\section{Kesimpulan}

Berdasarkan hasil pembahasan analisis data melalui pembuktian terhadap hipotesis dari permasalahan yang diangkat mengenai faktor yang mempengaruhi manajemen laba pada perusahaan perbankan yang terdaftar pada Bursa Efek Indonesia pada tahun 2012 hingga 2015, maka dapat diambil kesimpulan dari penelitian ini sebagai berikut:

1. Variabel kepemilikan manajerial, kepemilikan institusional, dan komite audit tidak berpengaruh terhadap Manajemen laba.

2. Variabel dewan komisaris independen, ukuran perusahaan dan laverage berpengaruh terhadap manajemen laba.

\section{Saran}

Bagi investor dan calon investor di Bursa Efek Indonesia disarankan untuk lebih mengkaji lagi faktor-faktor yang mempengaruhi manajemen laba. Karena campur tangan manjemen yang tinggi, cenderung akan melakukan manajemen laba dalam proses pelaporan keuangan dengan tujuan untuk menguntungkan diri sendiri. Bagi manajemen perusahaan untuk meningkatkan kepercayaan pemegang saham, maka manajemen perusahaan harus mampu mengoptimalkan kinerja keuangan maupun kinerja manajemen perusahaan pada tiap tahunnya, sehingga persepsi investor terhadap prospek kinerja perusahaan di masa yang akan datang dapat terjaga dengan baik.

\section{Keterbatasan}

Hasil penelitian menunjukkan bahwa nilai Adjusted R square dalam persamaan regresi pertama sebesar 0,162 yang berarti besar variansi manajemen laba pada persahaan perbankan yang terdaftar d BEI yang dapat diterangkan oleh variabel kepemiikan manajerial (KM), kepemilikan institusional (KI), komite audit (KA), dewan komisaris independen (DKI), ukuran perusahaan (size), dan leverage adalah sebesar 
16,2 persen sedangkan sisanya 83,8 persen dipengaruhi varibel lain di luar model penelitian.

\section{Agenda Penelitian Yang Akan Datang}

Dengan adanya keterbatasan hasil penelitian maka penelitian selanjutnya perlu dilakukan perbaikan agar hasilnya menjadi lebih baik maka penelitian selanjutnya, diharapkan dapat menguji faktor - faktor lain yang berhubungan dengan manajemen laba, serta memperpanjang periode penelitian.

\section{DAFTAR PUSTAKA}

Agustia, Dian, 2013 "PengaruhFaktorgood corporate governance, fre cash flowdanleverage terhadapmanajemenlaba." JurnalAkuntansi da Keuangan, Vol. 15, No. 1, 27-42, ISSN 1411-0288 print / ISSN 2338-8137 online

Boediono, G. SB. 2005. KualitasLaba: Study PengaruhCorporate GovernancedanDampakManajemenLabadenganMenggunakanAnalisisJalur. SimposiumNasional Indonesia VIII

Ghozali, Imam, 2011. AplikasiAnalisisMultivariate dengan Program IBM SPSS20, BadanPenerbitUniversitasDiponegoro

Gumanti, T.A, 2000. Earnings Managements: SuatutelaahPustaka. JurnalAkuntansidanKeuangan Vol.2, No. 2

http://www.idx.co.id/id-id/beranda/ perusahaantercatat /laporankeuangandan tahunan.aspx

http://www.idx.co.id/id-id/beranda/ publikasi /statistik.aspx

http://www.standford.edu (Tabel Durbin Watson)

KomiteNasionalKebijakanCorporate Governance, 2006. Pedomanumumgood corporate governance Indonesia

Mahawyahati, PutuTiyadanBudiasih, I GustiNyoman, 2016 "Asimetriinformasi, leverage, danukuranperusahaandanmanajemenlaba." JurnalIlmiahAkuntansidanBisnis, Vol. 11, No. 2

Pambudi, JanuarEkydanSumantri, FaridAddy, 2014 "Kualitas audit, ukuranperusahaandan leveragemanajemenlaba." SNA 17 Mataram, Lombok, UniversitasMataram 
Prabaningrat, I G A AdanWidanaputra, A. A. GP, 2015 "Pengaruhcorporate governance dankonservatismeakuntansipadamanajemenlaba." E-JurnalAkuntansiUniversitasUndayana10.3 : 663-667, ISSN : 2302-8556

Putri, I Gusti Made AsriDwija, 2012 "Pengaruh kebijakan dividen dan good corporate governance terhadapmanajemenlaba." Buletin Studi Ekonomi, Volume 7, No. 2, ISSN 1410-4628

Ridlo, Mukhlisur dan Kurnia, 2016 "Pengaruh kualitas dan corporate governance terhadap manajemen laba." Jurnal Ilmu dan Rise tAkuntansi : Volume 5, Nomer 2, ISSN : 2460-0585

Sirait, Christine Priskayani H dan Yasa, GerintaWirawan, 2015 "Pengaruh corporate governance terhadapa manajemen laba oleh CEO baru." E-Jurnal Akuntansi Universitas Udayana10.3 : 778-796, ISSN : 2302-8556

Siallagan, Hamongan dan Mas'ud, 2006 "Mekanisme corporate governance, kualitas laba dan nilai perusahaan.” SIMPOSIUM NASIONAL AKUNTANSI 9 PADANG

Sugiono, 2015. Metode Penelitian Pendidikan Pendekatan Kuantitatif, Kualitatif dan $\mathrm{R} \& \mathrm{D}$, ALFABETA

Sutikno, Frendy dan Wahidahwati, 2014 "Pengaruh corporate governance dan ukuran perusahaan terhadap manajemen laba di industry perbankan Indonesia."Jurnal Ilmu Akuntansi, Vol. 3 No. 10 
Majalah Ilmiah Solusi

Vol. 17, No. 2 April 2019

ISSN : 1412-5331

" Halaman ini sengaja di kosongkan " 